\title{
Aortic Valve Replacement
}

National Cancer Institute

\section{Source}

National Cancer Institute. Aortic Valve Replacement. NCI Thesaurus. Code C50815.

Surgery performed with the purpose of replacing a degenerated, calcified, malformed, dysfunctional, etc. aortic valve with a bioprosthetic, homograft, or autograft valve. 